\title{
RESEARCH JOURNAL TRANSPORT: REVIEWING PROCESS IN 2012
}

\author{
Olegas Prentkovskis \\ Managing Editor of the Research Journal TRANSPORT, Vilnius Gediminas Technical University, \\ Plytines g. 27, LT-10105 Vilnius, Lithuania \\ E-mail:olegas.prentkovskis@vgtu.lt
}

1 December 2012

At present, transport is one of the key branches playing a crucial role in the development of economy. Reliable and properly organized transport services are required for a professional performance of industry, construction and agriculture. The public mood and efficiency of work also largely depend on the valuable functions of a carefully chosen transport system. A steady increase in transportation is accompanied by growing demands for a higher quality of transport services and optimum efficiency of transport performance. Currently, joint efforts taken by the transport experts and governing institutions of the country are required to develop and enhance the performance of the national transport system conducting theoretical and empirical research.

The research journal TRANSPORT publishes articles in the fields of transport policy, fundamentals of the transport system, technology for carrying passengers and freight using road, railway, inland waterways, sea and air transport, technology for multimodal transportation and logistics, loading technology, roads, railways, airports, ports, pipeline transport, industrial and technological transport, agricultural motor vehicles, traffic safety and environment protection, design, manufacture and exploitation of motor vehicles, transport energetics, fuels, lubricants and maintenance materials, teamwork of customs and transport, insurance, transport information technologies, transport economics and management, transport standards, transport educology, transport history, etc.

Since 2010 research journal TRANSPORT uses ScholarOne Manuscripts (previously Manuscript Central) interactive system to peer review manuscript submissions.

All manuscripts, submitted through ScholarOne Manuscripts to the research journal TRANSPORT, are peer reviewed by the members of the Editorial Board or by the appointed experts. A minimal number of score sheets (filled by reviewers for one submitted manuscript by author) - 2, the average number of score sheets - 3.2.

The success and quality of a research journal TRANSPORT is to a great extent dependent on the activity and performance of its Editorial Board and Reviewers.

Thus, the again increased scientific content of the research journal TRANSPORT is also grateful to all reviewers; all those scientists that volunteer to contribute to improving the quality of our transport engineering and transport management fields by guiding the authors in their efforts to publishing their results.

On behalf of the Editorial Board of the research journal TRANSPORT I would like to thank the following reviewers for their important contribution to the quality of the journal in 2012 (papers submitted in 2011 and 2012, and part of them published in 2012):

AUSTRALIA

Demi Chung

University of Sydney

Geoffrey Clifton

University of Sydney

Corinne Mulley

University of Sydney

\section{BELGIUM}

Hongying Fei

University of Mons

Georges Kouroussis

University of Mons

Olivier Verlinden

University of Mons 
BRAZIL

Mário Ricardo Gongora-Rubio

IPT - Institute for Technological Research

CANADA

Zachary Patterson

University of Concordia

Maureen Reed

Ryerson University

\section{CHINA}

Liang Gao

Beijing Jiaotong University

Ying-En Ge

Dalian University of Technology

Yong-Gang Wang

Chang'an University

\section{CROATIA}

Mirano Hess

University of Rijeka

\section{CZECH REPUBLIC}

Jiří Chlebek

Brno University of Technology

Petr Porteš

Brno University of Technology

Libor Beneš

Czech Technical University in Prague

Vit Janoš

Czech Technical University in Prague

Josef Kocourek

Czech Technical University in Prague

Martina Lánská

Czech Technical University in Prague

Otto Pastor

Czech Technical University in Prague

Vladimír Uhříček

Czech Technical University in Prague

Jakub Gottvald

Vítkovice ÚAM, Inc.

Hana Jiránková

University of Pardubice

Michael Lata

University of Pardubice

Jaroslav Matuška

University of Pradubice

Jan Černý

University of Economics in Prague

\section{ESTONIA}

Andrus Aavik

Tallinn University of Technology

Dago Antov

Tallinn University of Technology

\section{FINLAND}

Pentti Kujala

Helsinki University of Technology

Jakub Montewka

Aalto University

Sari Repka

University of Turku

Wladimir Segercrantz

ANSERI-Consultants LTD

Ulla Tapaninen

University of Turku

\section{GERMANY}

Sergio Amancio

Helmholtz-Zentrum Geesthacht

\section{GREECE}

Konstantinos G. Zografos

Athens University of Economics and Business

George Giannopolos

Aristotle University of Thessaloniki

Zisis Samaras

Aristotle University of Thessaloniki

Josep Maria Salanova Grau

Hellenic Institute of Transport

Athanasios A. Pallis

University of the Aegean

\section{HUNGARY}

Ákos Bereczky

Budapest University of Technology and Economics Zoltan Bokor

Budapest University of Technology and Economics

Tamás Markovits

Budapest University of Technology and Economics

Tamás Péter

Budapest University of Technology and Economics

Katalin Tanczos

Budapest University of Technology and Economics

Ádám Török

Budapest University of Technology and Economics

Máté Zöldy

MOL DS Product Development

\section{ISLAMIC REPUBLIC OF IRAN}

Seyedreza Seyedalizadeh Ganji

Science and Research Branch of the Islamic Azad University

ITALY

Gianluca Dell'Acqua

University of Napoli Federico II

Cristina Pronello

Polytechnic University of Turin 


\section{LATVIA}

\section{Igor Kabashkin}

Transport and Telecommunication Institute Mareks Mezitis

Riga Technical University

Juris Smirnovs

Riga Technical University

Jänis Vìba

Riga Technical University

Irina Yatskiv

Transport and Telecommunication Institute

\section{LITHUANIA}

Algirdas Janulevičius

Aleksandras Stulginskis University

Violeta Makarevičiené

Aleksandras Stulginskis University

Gediminas Pupinis

Aleksandras Stulginskis University

Stasys Slavinskas

Aleksandras Stulginskis University

Rolandas Vitkūnas

International School of Law and Business

Žilvinas Bazaras

Kaunas University of Technology

Jonas Daunoras

Kaunas University of Technology

Algimantas Fedaravičius

Kaunas University of Technology

Vytautas Gargasas

Kaunas University of Technology

Paulius Griškevičius

Kaunas University of Technology

Jurga Ilgakojyté-Bazariené

Kaunas University of Technology

Janina Jablonskyte

Kaunas University of Technology

Artūras Keršys

Kaunas University of Technology

Robertas Keršys

Kaunas University of Technology

Dainius Martuzevičius

Kaunas University of Technology

Kęstutis Pilkauskas

Kaunas University of Technology

Henrikas Pranevičius

Kaunas University of Technology

Laurencas Raslavičius

Kaunas University of Technology

Jonas Sapragonas

Kaunas University of Technology

Ramūnas Skvireckas

Kaunas University of Technology

Arūnas Andziulis

Klaipeda University
Jolanta Janutèniené

Klaipeda University

Sergejus Lebedevas

Klaipeda University

Pranas Mažeika

Klaipeda University

Vytautas Paulauskas

Klaipeda University

Audra Skaisgirienè

Klaipeda University

Vytautas Smailys

Klaipeda University

Mindaugas Česnauskis

Klaipèda University

Ričardas Malkevičius

Lithuanian National Road Carriers Association LINAVA

Jurgita Barysiené

Ministry of Transport and Communications

of the Republic of Lithuania

Gražvydas Jakubauskas

Ministry of Transport and Communications

of the Republic of Lithuania

Vidmantas Pumputis

Ministry of Transport and Communications

of the Republic of Lithuania

Vitalija Rudzkiene

Mykolas Romeris University

Jurgita Antuchevičiené

Vilnius Gediminas Technical University

Juozas Bivainis

Vilnius Gediminas Technical University

Marijonas Bogdevičius

Vilnius Gediminas Technical University

Gintautas Bureika

Vilnius Gediminas Technical University

Marija Burinskiené

Vilnius Gediminas Technical University

Vytautas Grigonis

Vilnius Gediminas Technical University

Margarita Išoraité

Vilnius Gediminas Technical University

Marius Jakimavičius

Vilnius Gediminas Technical University

Aldona Jarašūniene

Vilnius Gediminas Technical University

Andrius Jaržemskis

Vilnius Gediminas Technical University

Raimundas Junevičius

Vilnius Gediminas Technical University

Algimantas Kajackas

Vilnius Gediminas Technical University

Ieva Meiduté

Vilnius Gediminas Technical University

Paulius Miškinis

Vilnius Gediminas Technical University

Saulius Nagurnas

Vilnius Gediminas Technical University 


\section{Narimantas Kazimieras Paliulis}

Vilnius Gediminas Technical University

Ramūnas Palšaitis

Vilnius Gediminas Technical University

Egidijus Petraitis

Vilnius Gediminas Technical University

Robertas Pečeliūnas

Vilnius Gediminas Technical University

Saugirdas Pukalskas

Vilnius Gediminas Technical University

Darius Rudinskas

Vilnius Gediminas Technical University

Henrikas Sivilevičius

Vilnius Gediminas Technical University

Edgar Sokolovskij

Vilnius Gediminas Technical University

Jūraté Sužiedelyté-Visockiené

Vilnius Gediminas Technical University

Jurijus Tretjakovas

Vilnius Gediminas Technical University

Zenonas Turskis

Vilnius Gediminas Technical University

Manuela Tvaronavičiené

Vilnius Gediminas Technical University

Rasa Ušpalytè-Vitkūniene

Vilnius Gediminas Technical University

Romualdas Vadlūga

Vilnius Gediminas Technical University

Egidijus Rytas Vaidogas

Vilnius Gediminas Technical University

Petras Vaitiekūnas

Vilnius Gediminas Technical University

Aidas Vasilis Vasiliauskas

Vilnius Gediminas Technical University

Vladas Vekteris

Vilnius Gediminas Technical University

Viktoras Vorobjovas

Vilnius Gediminas Technical University

Edmundas Kazimieras Zavadskas

Vilnius Gediminas Technical University

Virgilija Zinkevičiūte

Vilnius Gediminas Technical University

Marija Kučinskiené

Vilnius University

\section{POLAND}

\section{Leszek Golonka}

Wrocław University of Technology

Gabriel Nowacki

Motor Transport Institute

Wojciech Potkański

Institute of Aviation

Marek Sitarz

Silesian University of Technology

\section{RUSSIAN FEDERATION}

Ivan Dyakov

Ulyanovsk State Technical University

SERBIA

Jadranka Jović

University of Belgrade

\section{SLOVAKIA}

Norbert Adamko

University of Žilina

Karel Havel

University of Žilina

Antonin Kazda

University of Žilina

Peter Matis

University of Žilina

\section{SLOVENIA}

Bojan Beškovnik Intereuropa Ltd. Co.

Elen Twrdy

University of Ljubljana

Jana Šelih

University of Ljubljana

Uroš Klanšek

University of Maribor

SPAIN

Joaquim Casal

Polytechnic University of Catalonia

\section{SWEDEN}

Åsa Forsman

Swedish National Road and Transport Research Institute

Astrid Linder

Swedish National Road and Transport Research Institute

\section{SWITZERLAND}

Erik Wilhelm

Paul Scherrer Institute

\section{TURKEY}

Ali Payidar Akgüngör

Kirıkkale University

Serhan Tanyel

Dokuz Eylül University

\section{UKRAINE}

Andrii Bieliatynskyi

National Aviation University

Viktoriia Ivannikova

National Aviation University

Iryna Klymenko

National University of Transport

Maksym Starykov

Odessa National Maritime University 


\section{UNITED KINGDOM}

Ashraf El-Hamalawi

Loughborough University

Paul Fleming

Loughborough University

John Kinuthia

University of Glamorgan

Panos Konstantopoulos

University of Nottingham

Rawindaran Nair

Cardiff University

Karl Ropkins

University of Leeds

Felix Schmid

University of Birmingham

\section{UNITED STATES}

\section{Jing Dong}

Iowa State University

Kasthurirangan Gopalakrishnan

Iowa State University

Brian Wolshon

Louisiana State University

John D. Bullough

Rensselaer Polytechnic Institute

Leon James

University of Hawai'i System

Qian Zhou

University of Virginia 